\title{
PENGARUH RASIO MOL REAKTAN DAN LAMA SULFONASI TERHADAP KARAKTERISTIK METHYL ESTER SULFONIC (MES) DARI METIL ESTER MINYAK SAWIT
}

\author{
Effects of Mol Ratio and Sulfonation Time on Methyl Ester Sulfonic (MES) \\ Characteristics from Methyl Ester of Palm Oil
}

\section{Sri Hidayati ${ }^{1}$, Pudji Permadi ${ }^{2}$, Hestuti Eni ${ }^{3}$}

\author{
${ }^{1}$ Jurusan Teknologi Hasil Pertanian, Universitas Lampung, Jl. Sumantri Brojonegoro No. 1, Bandar Lampung 35145 \\ ${ }^{2}$ Jurusan Teknik Perminyakan, Fakultas Teknik Pertambangan dan Perminyakan, Institut Teknologi Bandung, \\ Gedung Labtek IV A Lantai 2, Jl. Ganesha No. 10, Bandung, 40132 \\ ${ }^{3}$ Pusat Penelitian dan Pengembangan Teknologi Minyak dan Gas Bumi, Lembaga Penelitian Minyak dan Gas, \\ Jl. Ciledug Raya, Kavling 109 Cipulir, Kebayoran Lama, Jakarta Selatan 12230 \\ Email: hidayati_thp@unila.ac.id
}

\begin{abstract}
ABSTRAK
Sebuah penelitian tentang proses produksi metil ester sulfonat menggunakan bahan baku metil ester minyak kelapa sawit dilakukan secara faktorial menggunakan $\mathrm{NaHSO}_{3}$ sebagai agen pensulfonasi dengan variasi rasio mol $\mathrm{NaHSO}_{3}$ 1:1,25, 1:1,5, 1:1,75 dan 1:2 dan lama sulfonasi.dengan variasi 3; 45; dan 6 jam. Hasil penelitian menunjukkan bahwa kondisi proses sulfonasi terbaik terdapat pada rasio metil ester dan mol reaktan 1:1,5 dan lama reaksi 4,5 jam dan suhu reaksi $100^{\circ} \mathrm{C}$ yang menghasilkan nilai stabilitas emulsi 68,25\%, bilangan asam 2,57 mg KOH/g sampel, bilangan iod 10,91 g Iod/100 g sampel. Konsentrasi metil ester sulfonat MES terbaik untuk menghasilkan IFT terendah adalah $1 \%$ (b/b) yaitu $1,806 \mathrm{dyne} / \mathrm{cm}$, salinitas optimal terjadi pada $20.000 \mathrm{ppm} \mathrm{NaCl}$ dengan nilai IFT $0,0055 \mathrm{dyne} / \mathrm{cm}$. Pemanasan pada suhu $80^{\circ} \mathrm{C}$ selama 30 hari dengan penambahan alkali $\mathrm{Na}_{2} \mathrm{CO}_{3} 1 \%(\mathrm{~b} / \mathrm{b})$ masih menghasilkan IFT 0,098 dyne/cm.
\end{abstract}

Kata kunci: MES, proses sulfonasi, $\mathrm{NaHSO}_{3}$

\begin{abstract}
An experiment of sulfonation process of methyl ester to produce methyl ester sulfonates (MES) was caried out using methyl ester palm oil in factorial design and $\mathrm{NaHSO}_{3}$ as sulfonating agent with variation of ratio mol $\mathrm{NaHSO}_{3}$ : methyl ester (1:1.25, 1:1.5, 1:1.75 and 1:2) and sulfonation time (3 hour (L1), 4.5 hour (L2) and 6 hour (L3). The result showed that the best sulfonation condition present in 1:1,5 mol ratio and sulfonation time of 4,5 hour. The best characteristic of MES was produced emulsion stability of $68.25 \%$, acid value of $2.57 \mathrm{mg} \mathrm{KOH} / \mathrm{g}$, iod value $10.91 \mathrm{~g}$ Iod/100 g sample, interfacial tension of $1.806 \mathrm{dyne} / \mathrm{cm}$ at MES concentration of $1 \%(\mathrm{w} / \mathrm{w})$. The optimal salinity occured at concentration of $20.000 \mathrm{ppm}$ which IFT value of $0.0055 \mathrm{dyne} / \mathrm{cm}$. Heating at a temperature of $80^{\circ} \mathrm{C}$ for 30 days with the addition of $1 \%(\mathrm{w} / \mathrm{w}) \mathrm{Na}_{2} \mathrm{CO}_{3}$ alkali still produce IFT 0.098 dyne $/ \mathrm{cm}$.
\end{abstract}

Keywords: MES, sulfonation, $\mathrm{NaHSO}_{3}$

\section{PENDAHULUAN}

Kelapa sawit merupakan salah satu komoditas perkebunan yang sangat penting di Indonesia. Untuk meningkatkan nilai tambah kelapa sawit, diperlukan upaya untuk meningkatkan produk sawit dari crude palm oil (CPO) sawit ke industri hilir kelapa sawit seperti industri oleokimia. Surfaktan yang dapat disintesa dari minyak sawit antara lain metil ester sulfonat (MES). MES memiliki kelebihan dibanding surfaktan yang berbasis petrokimia yaitu renewable, mudah didegradasi (good biodegradability), sifat deterjensi yang baik walaupun berada pada air dengan tingkat kesadahan yang tinggi (hard water), dapat mempertahankan aktivitas enzim yang lebih baik, toleransi yang lebih baik 
terhadap keberadaan kalsium, dan kandungan garam (disalt) lebih rendah (Matheson, 1996; Satsuki, 1992; Drozd, 1990; Aparicio dkk., 2012).

Metil ester sulfonat dapat disintesis dari beberapa tanaman seperti kelapa, kelapa sawit (CPO dan palm kernel oil (PKO), tallow dan kedelai (Sheats dan Arthur (2002); Norman dkk., 2008. Menurut Foster (1997), beberapa faktor yang sangat mempengaruhi kualitas MES adalah rasio mol, suhu reaksi, konsentrasi reaktan (gas $\mathrm{SO}_{3}$ ), $\mathrm{pH}$ netralisasi, lama penetralan, dan suhu selama penetralan. Proses sulfonasi dapat dilakukan dengan mereaksikan asam sulfat, sulfit, $\mathrm{NaHSO}_{3}$, atau gas $\mathrm{SO}_{3}$ dengan ester asam lemak (Bernardini, 1983; Watkins 2001).

Pada industri besar proses sulfonasi dilakukan dengan menggunakan gas $\mathrm{SO}_{3}$ sebagai reaktan (Ortega, 2012). Kelebihan gas SO3 sebagai agent pensulfonasi antara lain bersifat reaktif, menghasilkan konversi yang lebih sempurna, dan tidak terdapat limbah pada prosesnya (Mujdalifah dkk., 2012). Tetapi proses ini membutuhkan peralatan yang mahal dan kontrol yang sangat ketat karena gas $\mathrm{SO}_{3}$ memiliki sifat reaktifitas yang tinggi dan menghasilkan produk yang berwarna hitam. Untuk aplikasi lebih lanjut, warna produk yang hitam tersebut memerlukan proses pemucatan. Na-bisulfit $\left(\mathrm{NaHSO}_{3}\right)$ dapat digunakan karena memiliki keunggulan yaitu produk yang dihasilkan berwarna lebih cerah dan mudah diaplikasikan pada skala produk kecil. Penelitian penggunaan Na bisulfit sebagai reaktan pada proses pembuatan MES telah dilakukan oleh Hidayati dkk. (2006), Mansur dkk. (2007) Edison dan Hidayati (2009), Helianty dan Zulfansyah (2011).

Surfaktan memiliki kemampuan dalam menurunkan tegangan antarmuka/interfacial tension (IFT) dan stabilitas emulsi. Surfaktan mampu membentuk mikroemulsi karne memiliki nilai IFT yang rendah dan memiliki kapasitas untuk melarutkan antara minyak dan air. Ke depan akan lebih difokuskan penggunaan surfaktan dari bahan baku minyak nabati untuk deterjen dan Enhanced Oil Recovery (EOR) (Nagy dkk., 2014). Drelich dkk. (2002) melaporkan pada penggunaan surfaktan sebagai surfactant flooding sangat dipengaruhi oleh kemampuan surfaktan dalam menurunkan tegangan antarmuka. Dengan menurunnya tegangan antarmuka minyak-air, maka tekanan kapiler yang bekerja pada daerah penyempitan pori-pori akan berkurang, sehingga sisa minyak yang terperangkap dalam pori-pori batuan mudah didesak dan diproduksikan (Nuraini dkk., 2004).

Sugihardjo dkk. (2002) menyatakan bahwa faktor yang mempengaruhi efektivitas surfaktan dalam menurunkan tegangan antar muka minyak-air adalah jenis surfaktan yang digunakan, konsentrasi surfaktan dan co-surfaktan yang digunakan, kadar garam larutan dan adsorpsi larutan cosurfaktan sedangkan menurut Gomma (1997), kestabilan mikroemulsi dipengaruhi oleh salinitas, zat aditif, kesadahan, suhu dan tekanan. Hasil penelitian Hidayati (2006) menunjukkan bahwa penggunaan MES dari metil ester inti sawit pada konsentrasi $1 \%$ pada salinitas 20.000 ppm menghasilkan IFT $2,3^{-3}$ dyne/cm. Tujuan penelitian ini adalah mendapatkan rasio metil ester : mol reaktan dan lama sulfonasi yang menghasilkan MES dengan bahan baku dari metil ester kelapa sawit dengan kinerja yang sesuai dengan kriteria untuk surfactant flooding dalam Enhanced Oil Recovery (EOR).

\section{METODE PENELITIAN}

\section{Alat dan Bahan}

Peralatan yang digunakan dalam proses pembuatan metil ester sulfonat adalah seperangkat reaktor sulfonasi, sentrifius, rotor penggerak, alat timbang dan alat analisis uji kimia. Bahan yang digunakan untuk penelitian adalah: Metil ester dari metil ester minyak sawit, $\mathrm{NaHSO}_{3}$, metanol, $\mathrm{KOH}, \mathrm{NaOH}$, KI, Phenolptelin, KI, Na-thiosianat, $\mathrm{CHCl}_{3}$, pereaksi Wijs, $\mathrm{Na}_{2} \mathrm{~S}_{2} \mathrm{O}_{3}$, alkohol netral 95\%, $\mathrm{NaCl}, \mathrm{Na}_{2} \mathrm{CO}_{3}$ dan Xylene. Alat yang digunakan sebagai rangkaian seperti Gambar 1.

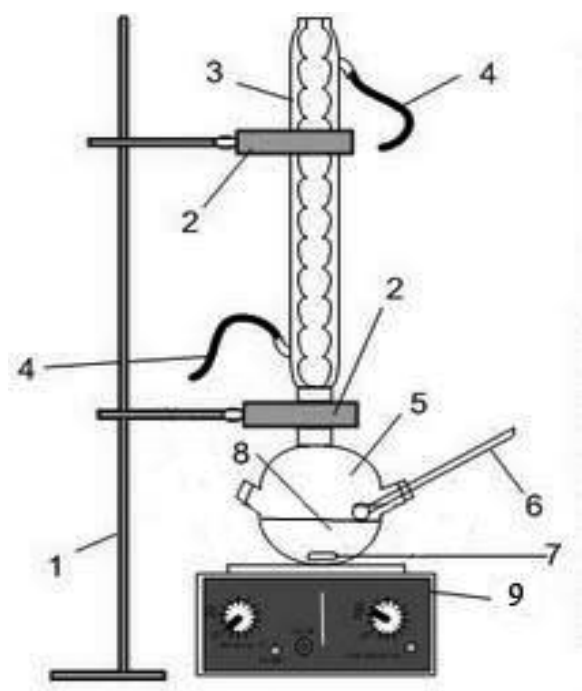

Keterangan Gambar: (1) Statip, (2) Klep statip, (3) Kondensor, (4) Selang inlet dan outlet air, (5) Labu leher tiga, (6) Thermometer, (7) Magnetic stirer, (8) Metil ester, (9) Hotplate stirer

Gambar 1. Peralatan pembuatan metil ester sulfonat

\section{Pembuatan MES dari Metil Ester Minyak Sawit}

Pada penelitian ini dilakukan uji pengaruh lama reaksi dan rasio metil ester : mol reaktan dengan menggunakan $\mathrm{NaHSO}_{3}$ sebagai bahan pensulfonasi. MES dibuat dengan bahan baku metil ester dari minyak sawit Penelitian dilakukan secara faktorial dalam Rancangan Acak Lengkap 
dengan perlakuan rasio mol 1:1,25, 1:1,5, 1:1,75 dan 1:2, dan lama reaksi adalah 3, 4,5, dan 6 jam dan diulang tiga kali. Data dianalisis dengan menggunakan uji lanjut Beda Nyata Terkecil pada taraf nyata 5\%. Setelah proses sulfonasi kemudian dilakukan proses pemurnian dengan menggunakan metanol $35 \%$ pada suhu $55^{\circ} \mathrm{C}$ selama 1,5 jam (Sherry dkk., 1995) dan dilakukan netralisasi dengan $\mathrm{NaOH} 20 \%$ dengan suhu $55^{\circ} \mathrm{C}$ selama 0,5 jam. Diagram alir dapat dilihat pada Gambar 2.

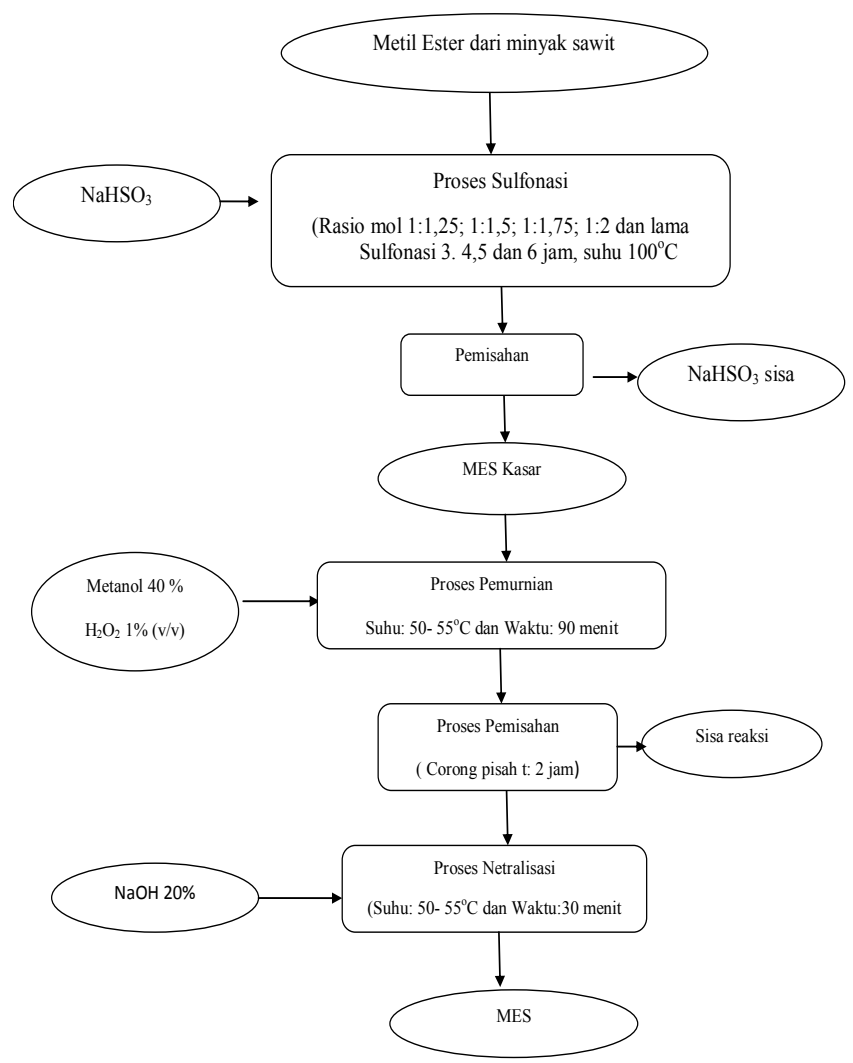

Gambar 2. Diagram alir proses tahapan penelitian pembuatan MES dari metil ester minyak sawit

\section{Analisis Sifat Fisiko Kimia MES}

Analisis yang dilakukan meliputi bilangan iod (AOAC 993.20 (1995) dan bilangan asam (AOAC 940.28 (1995), analisis tegangan antarmuka (IFT) dengan metode Gardener dan Hayes (1983) dan uji stabilitas emulsi (Modifikasi ASTM D 1436, 2001).

\section{HASIL DAN PEMBAHASAN}

Pengaruh Rasio Mol dan Lama Reaksi terhadap Tegangan Antar Muka (IFT) pada MES dari Metil Ester Minyak Sawit

Hasil penelitian menunjukkan bahwa rasio mol reaktan dan lama reaksi berpengaruh nyata $(\alpha=0,05)$ tetapi interaksi keduanya tidak berbeda nyata terhadap tegangan antar muka (Gambar 3). Tegangan antar muka adalah gaya persatuan panjang yang terdapat pada antarmuka dua fase cair yang tidak bercampur. Tegangan antarmuka menggunakan dua cairan yang berbeda tingkat kepolarannya, yaitu larutan surfaktan dengan beragam konsentrasi dan xilen (Adisalamun dkk., 2012). Pengujian dilakukan dengan menggunakan MES dengan konsentrasi $0,1 \%$ (b/b) dengan crude oil (Gambar 3).

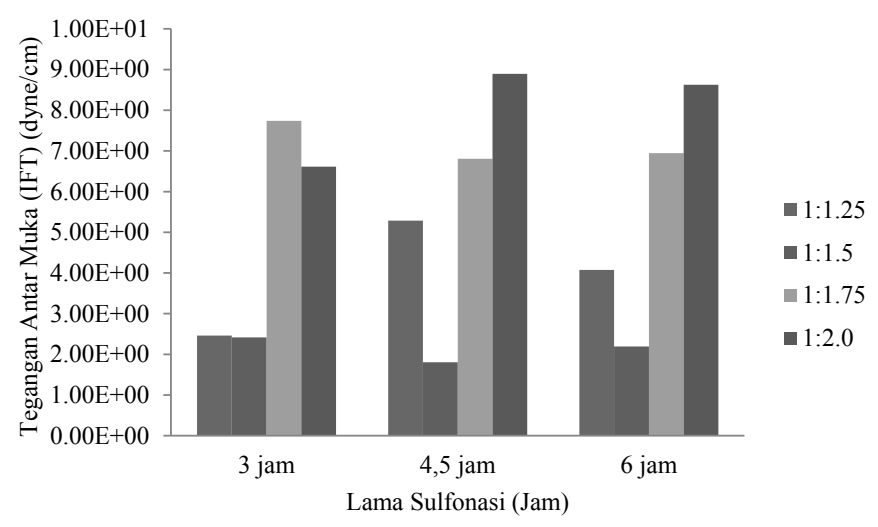

Gambar 3. Pengaruh rasio mol dan lama sulfonasi terhadap IFT pada MES dari metil ester minyak sawit

Hasil uji lanjut memperlihatkan bahwa lama sulfonasi berbeda nyata $(\alpha=0,05)$ dan semua perlakuan rasio mol berbeda nyata $(\alpha=0,05)$. Nilai IFT terkecil di peroleh pada perlakuan rasio mol reaktan 1:1,5 dan lama reaksi 4,5 jam. Peningkatan rasio mol reaktan dan lama sulfonasi dapat meningkatkan nilai tegangan antar muka. Hal ini disebabkan semakin besar rasio mol dan lama sulfonasi akan mengakibatkan proses oksidasi yang menghasilkan produk samping. Sheats dan Arthur (2002) menyatakan bahwa rasio mol reaktan yang digunakan untuk sulfonasi menggunakan gas $\mathrm{SO}_{3}$ pada kisaran 1:1,2 sampai 1:1,3. Pada waktu tahap pembentukan Metil Ester Sulfonic Acid (MESA), bila waktu sulfonasi terlalu lama, maka akan terjadi proses hidrolisis yang menghasilkan disalt (disodium karboksi sulfonat). Disalt dapat mengganggu bahkan menurunkan kinerja MES karena memiliki sifat yang tidak diinginkan yaitu tidak larut dalam air dan daya deterjensi yang lebih rendah 50\% dari MES (Adiandri, 2006) dan kemampuan MES untuk menurunkan tegangan antar muka berkurang.

Xie dkk. (2013) melaporkan kondisi sulfonasi terbaik diperoleh pada rasio mol reaktan 1:1,2 dengan menggunakan reaktan dari gas $\mathrm{SO}_{3}$ dengan konsentrasi $\alpha$-MES $86,3 \%$ dan disalt yang dihasilkan hanya $1,2 \%$ dan peningkatan rasio mol reaktan dapat meningkatkan pembentukan disalt. Elraies dkk. (2010) melaporkan bahwa penggunaan sodium methyl ester sulfonate (SMES) dari jarak pagar dapat menurunkan IFT larutan surfaktan dengan crude oil dari 18,4 menjadi 3,92 
dyne $/ \mathrm{cm}$.

\section{Pengaruh Rasio Mol dan Lama Reaksi terhadap Nilai Stabilitas Emulsi pada MES dari Metil Ester Minyak Sawit}

Hasil penelitian menunjukkan bahwa rasio mol metil ester : reaktan dan lama reaksi berpengaruh sangat nyata $(\alpha=0,01)$ dan interaksi keduanya berpengaruh sangat nyata $(\alpha=0,01)$ terhadap nilai stabilitas emulsi pada MES. Penambahan surfaktan pada suatu sistem koloid bertujuan untuk meningkatkan kestabilan dispersi fasa-fasa dengan cara mengurangi tegangan antar muka. Surfaktan yang bertindak sebagai emulsifier akan membentuk lapisan tipis yang akan menyelimuti partikel-partikel teremulsi dan mencegah partikel tersebut bergabung kembali dengan partikel sejenisnya (William dan Simons, 1992). Hasil penelitian stabilitas emulsi yang dihasilkan oleh proses sulfonasi pada penelitian ini berkisar 58-70\% (Gambar 4).

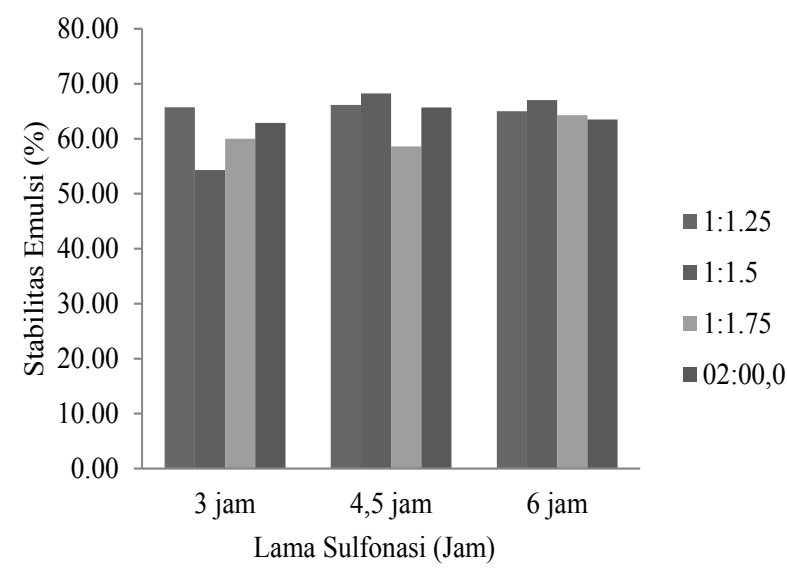

Gambar 4. Pengaruh rasio mol dan lama sulfonasi terhadap stabilitas emulsi pada MES dari metil ester minyak sawit

Hasil uji lanjut memperlihatkan bahwa hanya perlakuan rasio mol 1:2 dan lama waktu sulfonasi 3 jam yang berbeda $(\alpha=0,05)$ dengan perlakuan lain kecuali perlakuan perbandingan rasio mol 1:2 (3 jam), 1:1,5 (3 jam) dan 1:1,75 (4,5 jam). Peningkatan lama reaksi mengakibatkan penurunan stabilitas emulsi. Hal ini diduga akibat adanya reaksi hidrolisis MES yang menghasilkan senyawa samping seperti disalt yang tidak berfungsi sebagai surfaktan. Banyaknya jumlah gugus sulfonat yang terbentuk hal ini juga ditandai dengan penurunan bilangan iod yang menunjukkan adanya reaksi adisi oleh gugus sulfonat. Gugus sulfonat merupakan senyawa aktif penurun tegangan antar muka (IFT) dan tegangan permukaan dimana tegangan muka yang semakin kecil memungkinkan terbentuknya sebuah emulsi dan meningkatkan stabilitas emulsi (Hasenhuetti, 2000).

\section{Pengaruh Rasio Mol dan Lama Reaksi terhadap Bilangan Iod pada MES dari Metil Ester Berbasis Metil Ester Minyak Sawit}

Hasil penelitian menunjukkan bahwa rasio mol reaktan berpengaruh nyata $(\alpha=0,05)$ tetapi lama reaksi tidak berpengaruh nyata sedangkan interaksi keduanya berpengaruh nyata $(\alpha=0,05)$. Bilangan Iod merupakan salah satu parameter yang dapat digunakan sebagai indikator untuk mengetahui jumlah ikatan rangkap. Minyak/lemak yang memiliki jumlah ikatan rangkap lebih banyak akan memiliki bilangan iod yang lebih tinggi dibandingkan dengan minyak/lemak yang memiliki jumlah ikatan rangkap yang lebih sedikit. Penetapan bilangan iod dilakukan untuk mengetahui keberhasilan adisi gugus sulfonat ke dalam rantai minyak untuk membentuk gugus sulfonat. MES yang sempurna proses sulfonasinya akan menghasilkan bilangan iod yang rendah karena semua ikatan rangkap sudah diadisi secara sempurna (Rivai dkk., 2011).

Hasil pada penelitian menunjukkan respon bilangan iod yang dihasilkan oleh proses sulfonasi pada penelitian ini berkisar antara 8,88-11,93 gram iod/100 gram sampel. Menurut Rivai dkk. (2011), bilangan iod pada metil ester dari olein minyak sawit adalah $63 \mathrm{~g}$ Iod/100 g sampel.

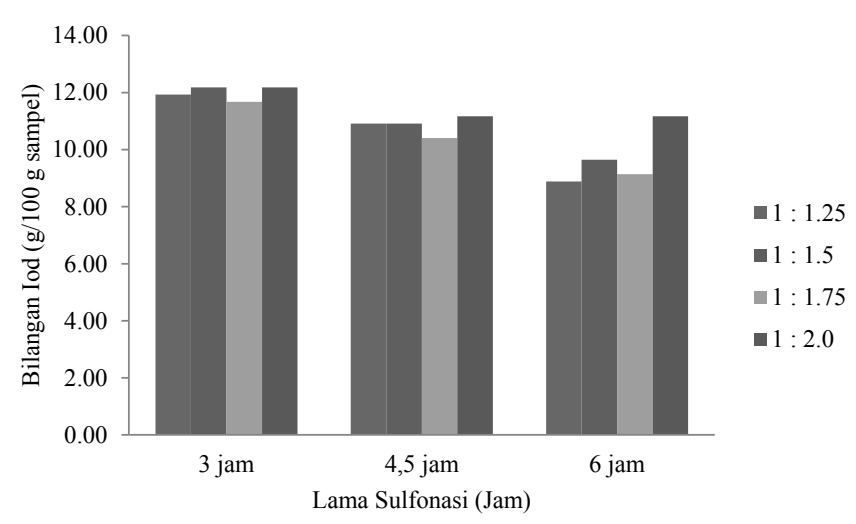

Gambar 5. Pengaruh rasio mol dan lama sulfonasi terhadap bilangan iod pada MES dari metil ester minyak sawit

Peningkatan lama reaksi dan rasio mol sampai 1:1,75 akan menyebabkan penurunan bilangan iod pada MES dari metil ester minyak sawit (Gambar 5). Hal ini diduga karena metil ester dari metil ester minyak sawit memiliki kandungan karoten yang merupakan senyawa dengan 11 ikatan rangkap dua sehingga ikut teradisi oleh Na-bisulfit. Proses ini memerlukan lama reaksi yang lebih besar untuk menurunkan bilangan iod.

Pore (1976) menyatakan bahwa untuk proses sulfonasi dengan menggunakan Na-bisulfit memerlukan suhu 60$100^{\circ} \mathrm{C}$ dan lama waktu 3-6 jam bahkan berlebih bila tidak menggunakan katalis. Mujdalipah dkk. (2012) melaporkan 
bahwa interaksi lama proses sulfonasi selama 60 dan 90 menit tidak memberikan pengaruh terhadap bilangan iod MES dari metil ester minyak goreng olein sawit dengan menggunakan reaktan gas $\mathrm{SO}_{3}$.

\section{Pengaruh Rasio Mol dan Lama Reaksi terhadap Bilangan Asam pada MES dari Metil Ester Minyak Sawit}

Hasil penelitian menunjukkan bahwa rasio mol reaktan dan lama reaksi berpengaruh nyata $(\alpha=0,05)$ serta interaksi keduanya berpengaruh nyata $(\alpha=0,05)$. Bilangan asam adalah bilangan yang menunjukkan banyaknya miligram $\mathrm{KOH}$ yang diperlukan untuk menetralkan satu gram lemak atau minyak. Ketika Na-bisulfit digunakan dalam proses sulfonasi maka akan meningkatkan bilangan asam. Bilangan asam yang dihasilkan oleh proses sulfonasi metil ester pada penelitian ini berkisar 1,45-6,34 mg KOH/g sampel (Gambar 6). Lama reaksi diatas 4 jam dan peningkatan rasio mol akan mengakibatkan reaksi tumbukan antar partikel Na-bisulfit dengan metil ester akan semakin cepat dan semakin tinggi gugus sulfonat yang dihasilkan sehingga meningkatkan bilangan asam dari MES dari metil ester minyak sawit.

Peningkatan lama reaksi dan rasio mol akan menyebabkan peningkatan pembentukan sulfon dan reaksi samping seperti asam-asam berantai pendek, pada degradasi yang lebih lanjut akan menghasilkan pembentukan asam sulfur yang menyebabkan peningkatan bilangan asam (Moreno dkk., 1988; Hu dan Tuvell, 1986; Dunn, 2002).

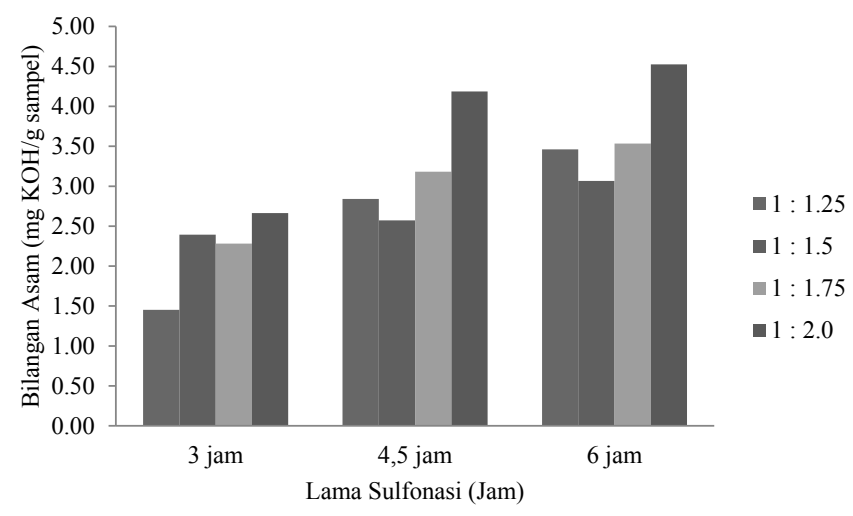

Gambar 6. Pengaruh rasio mol dan lama sulfonasi terhadap bilangan asam pada MES dari metil ester minyak sawit

Hasil percobaan menunjukkan bahwa semakin tinggi rasio mol dan lama sulfonasi dapat meningkatkan bilangan asam. Hal itu disebabkan terjadi pembentukan asam-asam oleh sulfat yang bersifat sebagai oksidator. Hasil penelitian
Mujdalifah dkk. (2012) menunjukkan bahwa semakin lama proses sulfonasi akan meningkatkan bilangan asam pada MES dari minyak goreng olein sawit.

\section{Uji Kinerja Surfaktan}

Pengujian kompabilitas dan pengukuran tegangan antar muka (IFT) diperlukan untuk mengetahui kinerja surfaktan MES sebagai chemical untuk Enhanced Oil Recovery (EOR). Diharapkan pada uji kompabilitas surfaktan akan larut sempurna dalam air, atau membentuk satu fasa. Dalam uji kinerja surfaktan maka digunakan sampel reservoar minyak dari lapangan yang merupakan minyak ringan (ligth oil) dan air formasi sintetik dengan kadar garam 10000 ppm.

Uji kompatibilitas. Hasil pengujian menunjukkan bahwa hampir semua larutan belum kompatibel dengan air formasi (brine). Adanya butiran dan lapisan minyak menunjukkan bahwa surfaktan tidak terlarut sempurna pada air formasi dan menghasilkan larutan dari jernih, light milky (susu agak encer), milky (seperti susu), keruh dan berbusa (Tabel 1).

Pengaruh konsentrasi MES terhadap tegangan antar muka (interfacial tension/ IFT). Hasil analisis ragam menunjukkan bahwa konsentrasi MES sangat berpengaruh nyata pada tingkat kepercayaaan $95 \%$ terhadap nilai tegangan antar muka (IFT). Hasil uji lanjut menunjukkan bahwa perlakuan konsentrasi MES $0,1 \%$ berbeda nyata dengan perlakuan lain tetapi perlakuan konsentrasi MES 1\% tidak berbeda nyata dengan perlakuan konsentrasi MES 2\% pada tingkat kepercayaan $95 \%$. Salah satu faktor yang berpengaruh terhadap nilai IFT adalah konsentrasi surfaktan. Efektivitas surfaktan dalam menurunkan tegangan antar muka minyak-air dipengaruhi oleh beberapa faktor, diantaranya jenis surfaktan yang digunakan, konsentrasi surfaktan dan co-surfaktan yang digunakan, kadar garam larutan dan adsorpsi larutan co-surfaktan (Sugihardjo dkk., 2002; Drelich dkk., 2002). Menurut Purnomo dkk. (2004), jika IFT diturunkan menjadi $10^{-3}$ dyne/cm maka fraksi minyak dalam residual oil yang terdapat pada porous media yang terjebak dapat dimobilisasi. Hasil pengujian menunjukkan bahwa semakin tinggi konsentrasi surfaktan dapat menurunkan tegangan antarmuka (IFT) (Gambar 7). Menurut Sheng (2011), penurunan IFT akan mencapai nilai minimum pada konsentrasi tertentu setelah itu akan mengalami kenaikan setelah melebihi nilai Critical Micelle Concentration (CMC). 
Tabel 1. Pengaruh konsentrasi surfaktan terhadap hasil uji kompabilitas MES

\begin{tabular}{|c|c|c|c|c|}
\hline \multirow[t]{2}{*}{ No } & \multirow[t]{2}{*}{ Nama Surafaktan } & \multirow{2}{*}{$\begin{array}{c}\text { Konsentrasi } \\
\text { surfaktan }\end{array}$} & \multicolumn{2}{|c|}{ Pengamatan kompabilitas } \\
\hline & & & Diam & Sesudah dikocok \\
\hline \multirow[t]{2}{*}{1} & Surfaktan Perlakuan A1 & 0,1 & Milky & Milky, keruh \\
\hline & & 2 & Milky, lapisan minyak & Milky \\
\hline \multirow[t]{2}{*}{2} & Surfaktan Perlakuan A2 & 0,1 & Milky & Milky \\
\hline & & 2 & Milky, berbusa, lapisan minyak & Milky, berbusa \\
\hline \multirow[t]{2}{*}{3} & Surfaktan Perlakuan A3 & 0,1 & Milky & Milky, berbusa \\
\hline & & 2 & Milky, lapisan minyak & Milky, berbusa \\
\hline \multirow[t]{2}{*}{4} & Surfaktan Perlakuan A4 & 0,1 & Jernih & Milky \\
\hline & & 2 & Milky, lapisan minyak & Milky, butiran minyak \\
\hline \multirow[t]{2}{*}{5} & Surfaktan Perlakuan A5 & 0,1 & Milky, lapisan minyak & Milky, butiran minyak \\
\hline & & 2 & Milky, berbusa, lapisan minyak & Milky, berbusa \\
\hline \multirow[t]{2}{*}{6} & Surfaktan Perlakuan A6 & 0,1 & Milky & Milky \\
\hline & & 2 & Milky, berbusa, lapisan minyak & Milky, berbusa, lapisan minyak \\
\hline \multirow[t]{2}{*}{7} & Surfaktan Perlakuan A7 & 0,1 & Milky & Milky \\
\hline & & 2 & Milky, lapisan minyak & Milky, berbusa \\
\hline \multirow[t]{2}{*}{8} & Surfaktan Perlakuan A8 & 0,1 & Milky, lapisan minyak & Milky \\
\hline & & 2 & Milky, lapisan minyak & Milky, kekuningan \\
\hline \multirow[t]{2}{*}{9} & Surfaktan Perlakuan A9 & 0,1 & Milky & Milky, butiran minyak \\
\hline & & 2 & $\begin{array}{l}\text { Milky, lapisan minyak, } \\
\text { kekuningan }\end{array}$ & Milky, butiran minyak, berbusa \\
\hline \multirow[t]{2}{*}{10} & Surfaktan Perlakuan A10 & 0,1 & Milky, lapisan minyak & Milky, berbusa \\
\hline & & 2 & Milky, lapisan minyak & Milky, berbusa \\
\hline \multirow[t]{2}{*}{11} & Surfaktan Perlakuan A11 & 0,1 & Jernih & Milky \\
\hline & & 2 & $\begin{array}{l}\text { Milky, lapisan minyak, } \\
\text { kekuningan }\end{array}$ & Milky, berbusa \\
\hline \multirow[t]{2}{*}{12} & Surfaktan Perlakuan A12 & 0,1 & Jernih, lapisan minyak & Milky \\
\hline & & 2 & $\begin{array}{l}\text { Milky, lapisan minyak, } \\
\text { kekuningan }\end{array}$ & Milky, berbusa \\
\hline
\end{tabular}

Keterangan:
$\mathrm{A} 1=$ rasio mol 1:1,25, lama reaksi 3 jam
$\mathrm{A} 2=$ rasio mol 1:1,25, lama reaksi 4,5 jam
$\mathrm{A} 3=$ rasio mol 1:1,25, lama reaksi 6 jam
A4 = rasio mol 1:1,5, lama reaksi 3 jam
A5 $=$ rasio mol 1:1,5, lama reaksi 4,5 jam
$\mathrm{A} 6=$ rasio mol 1:1,5, lama reaksi 6 jam
$\mathrm{A} 7=$ rasio mol 1:1,75, lama reaksi 3 jam
$\mathrm{A} 8=$ rasio mol 1:1,75, lama reaksi 4,5 jam
A9 $=$ rasio mol 1:1,75, lama reaksi 6 jam
$\mathrm{A} 10=$ rasio mol 1:2, lama reaksi 3 jam
$\mathrm{A} 11=$ rasio mol 1:2, lama reaksi 4,5 jam
$\mathrm{A} 12=$ rasio mol 1:2, lama reaksi 6 jam 


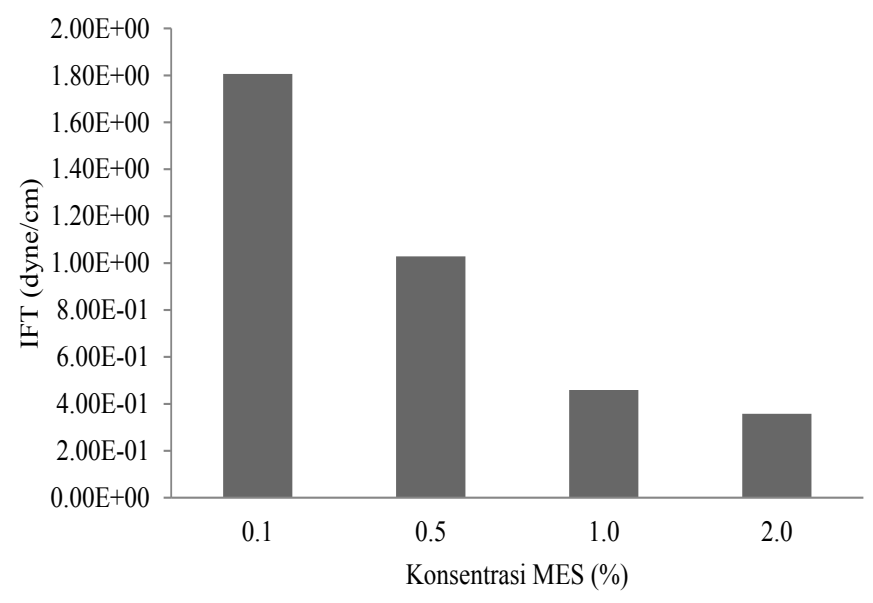

Gambar 7. Pengaruh konsentrasi MES (\%) terhadap nilai IFT

Pengaruh lama simpan pada uji termal stabilitas suhu $80^{\circ} \mathrm{c}$ penambahan $1 \% \mathrm{Na}_{2} \mathrm{CO}_{3}$.

Hasil analisis ragam menunjukkan bahwa lama waktu simpan pada uji stabilitas suhu $80^{\circ} \mathrm{C}$ penambahan $1 \% \mathrm{Na}_{2} \mathrm{CO}_{3}$ sangat berpengaruh nyata pada tingkat kepercayaan 95\% terhadap nilai tegangan antar muka (IFT). Hasil uji lanjut menunjukkan perbedaan nyata pada perlakuan penyimpanan hari ke 1 dengan hari ke 3, 7, 14, dan 30 dengan tingkat kepercayaan 95\%. Untuk meningkatkan kinerja surfaktan dapat dilakukan penambahan alkali pada formulasi surfaktan seperti $\mathrm{KOH}, \mathrm{NaOH} 0$ - 1,6 \% (w/w) (Nedjhioui dkk., 2005), dan $\mathrm{Na}_{2} \mathrm{CO}_{3} 0$ - 0,6 \% (Carrero dkk., 2006). Menurut Jackson (2006), penambahan natrium karbonat/sodium carbonate digunakan karena dapat menurunkan adsorpsi surfaktan anionik pada batuan reservoir dan membantu menjaga kestabilan beberapa surfaktan dan dapat pula digunakan dalam memperbaiki hidrasi polimer. Sugihardjo dkk. (2002) menyatakan bahwa alkali/aditif yang boleh dipergunakan adalah dengan batas maksimal penggunaan $1 \%$ untuk memaksimalkan kinerja surfaktan dalam menurunkan tegangan antarmuka. Sheng (2011) melaporkan terdapat 6 alkali yang dapat digunakan untuk menurunkan IFT adalah $\mathrm{Na}_{3} \mathrm{PO}_{4}, \mathrm{NaHCO}_{3}, \mathrm{NaOH}, \mathrm{Na}_{2} \mathrm{SiO}_{3}, \mathrm{Na}_{4} \mathrm{SiO}_{4}$, dan $\mathrm{Na}_{2} \mathrm{CO}_{3}$. Penambahan alkali seperti natrium karbonat meningkatkan kekuatan ion.

Sugihardjo dkk. (2001) menyatakan bahwa salah satu faktor yang mempengaruhi efektivitas formula surfaktan selama mengalir dalam media berpori adalah adanya degradasi molekul surfaktan yang disebabkan oleh suhu yang tinggi karena menurut Ayirala (2002) agar surfaktan berpindah melewati pori batuan reservoir dan mengubah wettability permukaan pori batuan perlu waktu yang cukup lama dan harus dilakukan uji thermal stability untuk mengetahui daya tahan larutan surfaktan terhadap panas pada suhu reservoar. Hasil pengujian menunjukkan bahwa semakin lama waktu simpan dapat meningkatkan nilai IFT pada surfakatan yang telah dipanaskan pada suhu $80^{\circ} \mathrm{C}$ (Gambar 8$)$.

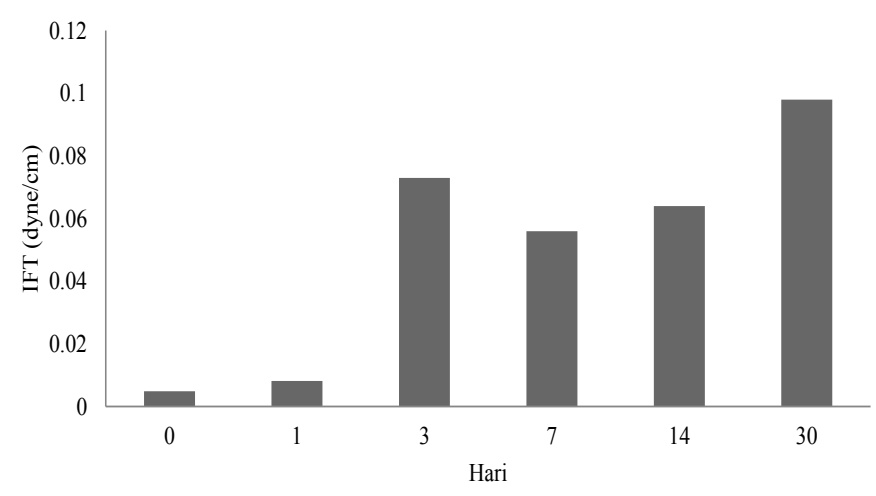

Gambar 8. Pengaruh lama waktu simpan terhadap IFT MES yang dipanaskan pada suhu $80^{\circ} \mathrm{C}$

Peningkatan nilai IFT terjadi diduga karena penyimpanan pada waktu yang lama akan menyebabkan konsentrasi elektrolit menjadi tinggi. Dimana micelle yang terbentuk pada fasa cair menjadi berkurang, sehingga proses difusi dan adsorpsi surfaktan yang terjadi pada bidang batas menjadi berkurang, sehingga menyebabkan IFT menjadi meningkat (Zhao dkk., 2005). Tobing dan Eni (2013) melaporkan hasil uji thermal stability terhadap larutan ASP (1\% alkali Na2CO3 $+0.1 \%$ surfaktan +750 ppm polimer). Harga IFT larutan ASP mengalami kenaikan sebanyak 16 kali dari 3.77x10-3 pada hari ke-0 (sebelum dipanaskan) sampai harga $6.03 \times 10^{-2}$ dyne/ cm pada hari ke-30.

Pengaruh konsentrasi NaCl terhadap IFT. Hasil analisis ragam menunjukkan bahwa konsentrasi $\mathrm{NaCl}$ sangat berpengaruh nyata terhadap nilai tegangan antar muka (IFT) dengan tingkat kepercayaan 95\%. Hasil uji lanjut menunjukkan bahwa perlakuan konsentrasi $\mathrm{NaCl} 10.000$ ppm berbeda nyata dengan perlakuan konsentrasi $\mathrm{NaCl} 20.000$, 30.000 , 40.000 dan 50.000 ppm pada tingkat kepercayaan 95\%. Menurut Sugihardjo dkk. (2002), efektivitas surfaktan untuk menurunkan IFT dipengaruhi oleh diantaranya jenis surfaktan yang digunakan, konsentrasi surfaktan dan cosurfaktan yang digunakan, kadar garam larutan dan adsorpsi larutan co-surfaktan. Healy dan Reed (1974) mempelajari pengaruh konsentrasi garam $\mathrm{NaCl}$ terhadap tegangan antar muka. Tingkat salinitas yang menghasilkan IFT paling rendah disebut sebagai optimal salinity. Sampath dkk. (1998), menyatakan bahwa larutan garam (brine) berfungsi sebagai larutan ektrolit yang diperlukan untuk menurunkan IFT.

Hasil penelitian menunjukkan bahwa optimal salinity terjadi pada konsentrasi $\mathrm{NaCl} 20.000$ ppm setelah terjadi kenaikan IFT akibat peningkatan konsentrasi $\mathrm{NaCl}$ (Gambar 9). 


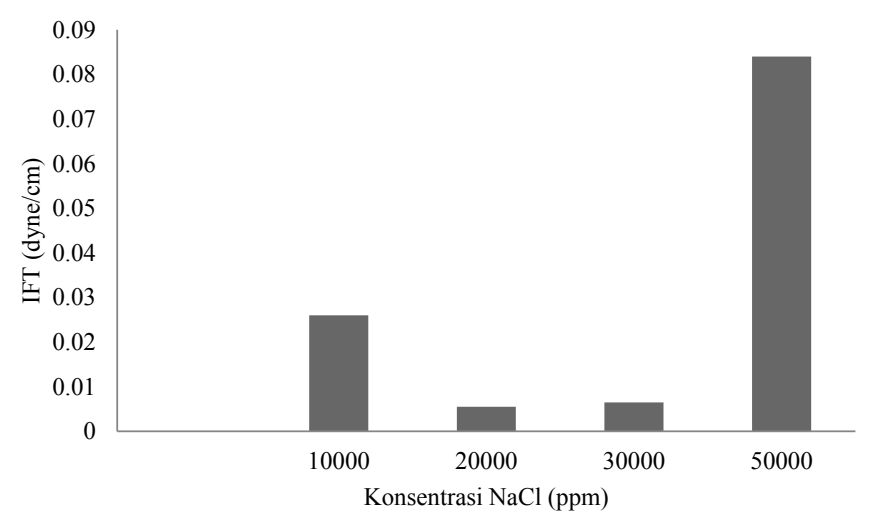

Gambar 9. Pengaruh konsentrasi $\mathrm{NaCl}$ terhadap IFT MES

Hasil penelitian yang dilakukan Sampath dkk. (1998) menunjukkan bahwa nilai IFT meningkat seiring dengan meningkatnya salinitas atau kadar garam. Hal ini disebabkan karena ikatan kimia yang membentuk $\mathrm{NaCl}$ adalah ikatan ion yang sangat mudah terurai menjadi ion $\mathrm{Na}+$ dan ion $\mathrm{Cl}-$, begitu juga halnya dengan molekul-molekul surfaktan. Di dalam air surfaktan akan mudah terurai menjadi ion $\mathrm{RSO}_{3}^{-}$ dan $\mathrm{H}^{+}$. Jika pada operasi injeksi surfaktan terdapat garam $\mathrm{NaCl}$, maka akan membentuk $\mathrm{HCl}$ dan $\mathrm{RSO}_{3} \mathrm{Na}$, dimana $\mathrm{Ca}$ dan $\mathrm{RSO}_{3} \mathrm{Na}$ bukan merupakan zat aktif permukaan dan tidak dapat menurunkan tegangan permukaan. Hasil uji kelakuan fasa menunjukkan bahwa semakin tinggi salinitas akan membentuk fraksi oil wet sehingga terjadi peningkatan IFT (Ashayer-Soltani dkk., 1999).

\section{KESIMPULAN}

Hasil optimasi proses pembuatan MES berbahan baku metil ester dari metil ester minyak sawit menunjukkan bahwa kondisi kombinasi perlakuan terbaik dengan menggunakan rasio mol 1:1,5 dan lama reaksi 4,5 jam pada suhu reaksi $100^{\circ} \mathrm{C}$ dengan nilai stabilitas emulsi $68,25 \%$, bilangan asam 2,57 $\mathrm{mg} \mathrm{KOH} / \mathrm{g}$ sampel, bilangan iod 10,91g Iod/100 g sampel. Konsentrasi MES terbaik untuk menghasilkan IFT terendah adalah $1 \%$ yaitu $1,806 \mathrm{dyne} / \mathrm{cm}$, salinitas optimal terjadi pada $20.000 \mathrm{ppm} \mathrm{NaCl}$ dengan nilai IFT 0,0055 dyne/cm. Pemanasan pada suhu $80^{\circ} \mathrm{C}$ selama 30 hari dengan penambahan alkali $\mathrm{Na}_{2} \mathrm{CO}_{3} \quad 1 \%$ mampu mempertahankan nilai IFT hingga 0,098 dyne/cm.

\section{DAFTAR PUSTAKA}

Adisalamun, Mangunwidjaja, D., Suryani, A., Sunarti, T.C. dan Arkeman, Y. (2012). Adsorpsi surfaktan nonionik alkil poliglikosida pada antarmuka fluida-fluida. Jurnal Rekayasa Kimia dan Lingkungan 9(1): 1-5.
Adiandri, R.S. (2006). Kajian Pengaruh Konsentrasi Metanol dan Lama Reaksi pada Proses Pemurnian Metil Ester Sulfonat terhadap Karakteristik Detergen Bubuk. Tesis. Fakultas Teknologi Pertanian. Institut Pertanian Bogor, Bogor.

American Society for Testing and Material (ASTM) (2001). Annual Book of ASTM Standards: Soap and Other Detergents, Polishes, Leather, Resilient Floor Covering. ASTM, Baltimore.

AOAC 993.20. (1995). Official Method of Analysis of the Association of Official Analytical Chemist, AOAC, Washington.

AOAC 940.28. (1995). Official Method of Analysis of the Association of Official Analytical Chemist, AOAC, Washington.

Aparicio, J., MacArthur, B.W., Sheats, W.B. dan Brooks, B.J. (2012). MES - myths, mysteries and perspectives on properties and use. International Conference of Surfactant and Detergent 2012, Shanghai, PRC, April 2012.

Ashayer-Soltani, R. (1999). Surfactant Phase Behaviour in relation to Oil Recovery. Disertasi. Imperial College, London.

Ayirala, S. (2002). Surfactant-Induced Relative Permeability Modifications for Oil Recovery Enhancement. Tesis. Lousiana State University and Agricultural and Mechanical College.

Bernardini, E. (1983). Vegetable Oils and Fats Processing. Volume II. Interstampa, Rome.

Carrero E., Queipo, N.V., Pintos, S. dan Zerpa, L.E. (2006). Global sensitivity analysis of alkali-surfactant-polymer enhanced oil recovery processes. Journal of Petroleum Science and Engineering 58: 30-42.

Dunn, R. (2002). Effect of oxidation under accelerated conditions on fuel properties of methyl soya (biodiesel). Journal of the American Oil Chemists' Society 79(9): 915-919.

Drelich. J., Fang, C.H. dan White, C.L. (2002). Measurement of Interfacial Tension in Fluid-Fluid Systems. Marcel Dekker, Inc.

Drozd, J.C. (1990). Use of sulfonated methyl esters in household cleaning products. Proceedings of World Conference on Oleochemicals into the $21^{\text {st }}$ Century, AOCS. Hal.: 256-268.

Edison, R. dan Hidayati, S. (2009), Production surfactant methyl ester sulfonate (MES) of jatropha oil (Jatropha 
curcas L.) with temperature and time sulfonation, temperature purification, and concentration methanol settings. Proceeding International Seminar on Sustainable Biomass Production and Utilization Challenges and Oppurtunities (ISOMASS) August.

Elraies, K.A., Tan, I. M., M. Awang, M. dan Saaid, I. (2010). The synthesis and performance of sodium methyl ester sulfonate for enhanced oil recovery. Petroleum Science and Technology 28(17): 1799-1806.

Foster, N.C. (1997). Sulfonation and sulfation processes. Dalam: Spitz, L. (Ed). Soap and Detergents: $A$ Theoretical and Practical Review. AOCS Press, Champaign, Illinois.

Gardener, J.E. dan Hayes, M.E. (1983). Spining Drop Interfacial Tensiometer Instruction Manual. Departement of Chemistry, University of Texas, Texas.

Gomma, E.E. (1997). Enhanced oil recovery: modern management aproach : Paper for IATMI-IWPL/MIGAS Conference, Surakarta, 28 Juli-1 Agustus 1997.

Hassenhuetti, G.H. (2000). Design and application of fatbased surfactant. Dalam: O'Brien, R.D., Farr, W.E dan Wan, P.J. (ed). Introduction To Fat And Oil Technology. AOAC Press, Illinois USA.

Healy, R.H. dan Reed, R.L. (1974). Immiscible microemulsion flooding. Society of Petroleum Engineer 5817: 129-139.

Helianty, S. dan Zulfansyah (2011). Pembuatan ester metil sulfonat dari ester metil palm stearin. Jurnal Teknobiologi II(1): 37-39.

Hidayati, S., Suryani, A., Permadi, P., Hambali, H., Syamsu, K. dan Sukardi (2006). Optimasi proses pembuatan metil ester sulfonat dari minyak inti sawit. Jurnal Teknik Industri 15 (3): 96-101.

Hidayati, S. (2006). Perancangan Proses Produksi Metil Ester Sulfonat dari Minyak Sawit Inti Sawit dan Uji Efektivitasnya untuk Pendesakan Minyak Bumi. Disertasi. Institut Pertanian Bogor, Bogor, Indonesia.

Hu, P.C. dan Tuvell, M.E. (1988). A mechanistic approach to the thermal degradation of $\alpha$ olefin sulfonates. Journal of the American Oil Chemists' Society 65(6): 10071012.

Jackson, A.C. (2006). Experimental Study of the Benefits of Sodium Carbonate on Surfactants for Enhanced Oil Recovery. Thesis. University of Texas at Austin, Austin Texas.

Mansur, D., Astrini, N. dan Tasrif (2007). Sodium bisulfite as $\mathrm{SO}_{3}$ source for synthesis of methyl ester sulfonate using RBD stearin as raw material. The Journal for Technology and Science 18(4): 116-122.

Matheson, K.L. (1996). Surfactant raw materials: classification, synthesis, and uses. Dalam: Spitz, L. (Ed). Soap and Detergents: A Theoretical and Practical Review. AOCS Press, Champaign, Illinois.

Moreno, J.B., Bravo, J. dan Berna, L.J. (1988). Influence of sulfonated material and its sulfone content on the physical of linier alkyl benzene sulfonates. Journal of the American Oil Chemists 'Society 65(6): 1000-1006.

Mujdalipah, Hambali, E., Suryani, A. dan Zulchaidir, E. (2012). Pengaruh suhu dan lama proses sulfonasi dalam proses produksi methyl ester sulfonic acid (MESA) menggunakan single tube falling film reactor (STFR). Agritech 32(3): 275-283.

Nagy, R., Bartha, L., Toth, J. dan Vágo, A. (2014). Study on characteristics of micelles formed by surfactants and polymer mixtures for enhanced oil recovery. Chemical Engineering Transactions 36: 217-222.

Nedjhioui, M., Mostefa, M. N., Morsli, A. dan Bensmaili, A. (2005). Combined effects of polymer/surfactant/oil/ alkali on physical chemical properties. Desalination 185: 543-550.

Norman, F., Brian, M., Sheats, W.B., Michael, S. dan Sanjay, T. (2008). Handbook of Detergents, Part F: Production of Methyl Ester Sulfonates. CRC Press.

Nuraini, Sugihardjo, dan Makmur, T. (2004). Uji kelakuan fase dan tegangan antarmuka minyak-surfaktankosurfaktan-air injeksi. Pusat Penelitian dan Pengembangan Teknologi Minyak dan Gas Bumi 38(1): 20-25.

Ortega, J.A.T. (2012). Sulfonation/sulfation processing technology for anionic surfactant manufacture. http:// www.intechopen.com. [1 April 2014].

Pore, J. (1976). Oil and Fat Manual. Intercept Ltd, Andover, U.K, Paris, New York.

Purnomo, H., Nuraini dan Tjuwati, M. (2004). The influence of alcohol type and concentration of the phase behaviour and interfacial tension in oil surfactant-cosurfactantbrine mixture system. Lemigas Scientief Contributions 27(2): 43-49.

Rivai, M., Irawadi, T.T., Suryani, A., Setyaningsih, D. dan Hambali, E. (2011). Penentuan lama sulfonasi pada proses produksi surfaktan MES untuk aplikasi EOR. Jurnal llmu Pertanian Indonesia 16(1): 28-34.

Sampath, R., Moeti, L.T., Pitts, M.J. dan Smith, D.H. (2003). Characterization of Surfactant for Enhanced Oil 
Recovery. Departement of Engineering, Clarck Atlanta University, Atlanta.

Satsuki, T. (1992). Applications of MES in detergents. INFORM 3(10): 1099.

Sheats, W.B. dan Arthur, B.W. (2002). Methyl ester sulfonate products. W. Brad Sheats, Dr. Brian W. MacArthur. "Methyl ester sulfonate products" http://www. chemithon.com/Resources/pdfs/Technical papers/ Methyl\%20Ester\%20Sulfonate\%20Products\%20 5th\%20Cesio\%20v19,R1.pdf. [26 Februari 2003].

Sherry, A.E., Chapman, B.E., Creedon, M.T., Jordan, J.M. dan Moese, R.L. (1995). Nonbleach process for the purification of palm C16-18 methyl ester sulfonates. Journal America Oil Chemistry Society 72(7): 835-841.

Sheng, J.J. (2011). Modern Chemical Enhanced Oil Recovery: Theory and Practice. Gulf Professional Publishing is An Imprint of Elsevier. 30 Corporate Drive, Suite 400. Burlington, MA 01803, USA.

Sugiharjdo, Tobing, E. dan Pratomo, S.W. (2001). Kelakuan fasa campuran antara "reservoir-injeksi-surfaktan" untuk implementasi enhanced water flooding. Prosiding Simposium Nasional IATMI. Yogyakarta 3-5 Oktober 2001.
Sugihardjo (2002). Formulasi optimum campuran surfaktan, air dan minyak. Lembaran Publikasi Lemigas 36(3): 37-42.

Tobing, E.M.L. dan Eni, H. (2013). Peningkatan perolehan reservoir minyak ' $R$ ' dengan injeksi alkali-surfaktanpolimer pada skala laboratorium. Lembaran Publikasi Minyak dan Gas Bumi 47(2): 87-96.

Watkins, C. (2001). All eyes are on Texas. INFORM 12: 1152-1159.

Williams, R.A. dan Simons, S.J.R. (1992). Handling colloidal materials. Dalam: Williams, R.A. (Ed.). Colloid and Surface Engineering: Applications in the Process Industries. Butterworth Heinemann Ltd., Oxford.

Xie, T., Zeng, C., Wang, C. dan Zhang, L. ( 2013). Preparation of methyl ester sulfonates based on sulfonation in a falling film microreactor from hydrogenated palm oil methyl esters with gaseous $\mathrm{SO}_{3}$. Industrial and Engineering Chemistry Research 52(10): 3714-3722.

Zhao, Z., Li, Z., Qiao, W. dan Cheng, L. (2005). Dynamic interfacial behaviour between crude oil and octyl methyl naphtalena sulfonate surfactant flooding system. Colloids and Surfaces 259(1-3): 71-80. 